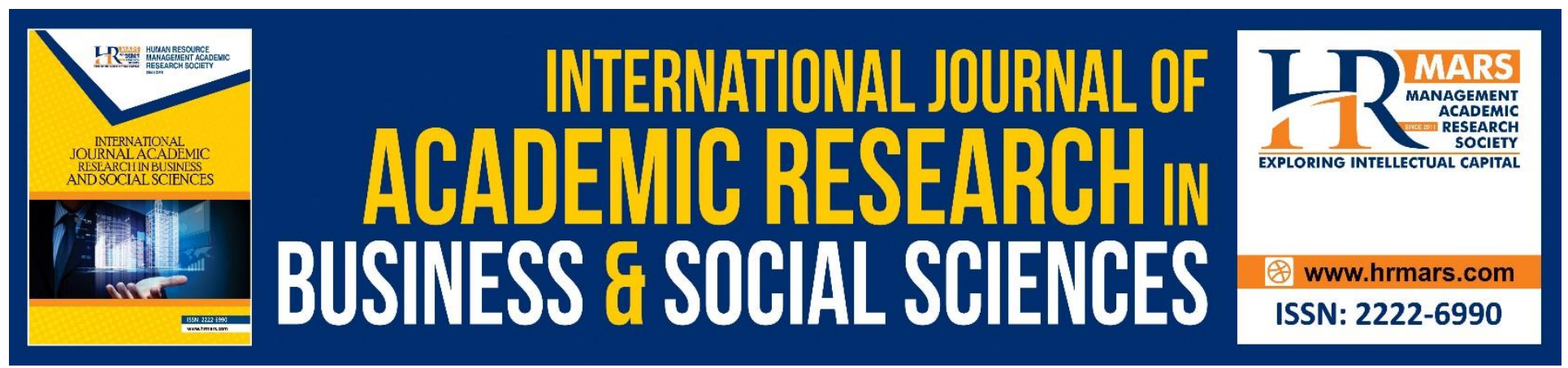

\title{
Teaching Professors' Challenges about Community Engagement Outreach and Intervention in Nigerian Universities
}

Samuel Outokunbo Adekalu, Steven Eric Krauss, Ismi Arif Ismail, Turiman Suandi

To Link this Article: http://dx.doi.org/10.6007/IJARBSS/v8-i8/4458

DOI: $\quad 10.6007 /$ IJARBSS/v8-i8/4458

Received: 07 July 2018, Revised: 23 July 2018, Accepted: 19 August 2018

Published Online: 29 August 2018

In-Text Citation: (Adekalu, Krauss, Ismail, \& Suandi, 2018)

To Cite this Article: Adekalu, S. O., Krauss, S. E., Ismail, I. A., \& Suandi, T. (2018). Teaching Professors' Challenges about Community Engagement Outreach and Intervention in Nigerian Universities. International Journal of Academic Research in Business and Social Sciences, 8(8), 191-204.

Copyright: (c) 2018 The Author(s)

Published by Human Resource Management Academic Research Society (www.hrmars.com)

This article is published under the Creative Commons Attribution (CC BY 4.0) license. Anyone may reproduce, distribute, translate and create derivative works of this article (for both commercial and non-commercial purposes), subject to full attribution to the original publication and authors. The full terms of this license may be seen at: http://creativecommons.org/licences/by/4.0/legalcode

Vol. 8, No. 8, August 2018, Pg. 191 - 204

Full Terms \& Conditions of access and use can be found at http://hrmars.com/index.php/pages/detail/publication-ethics 


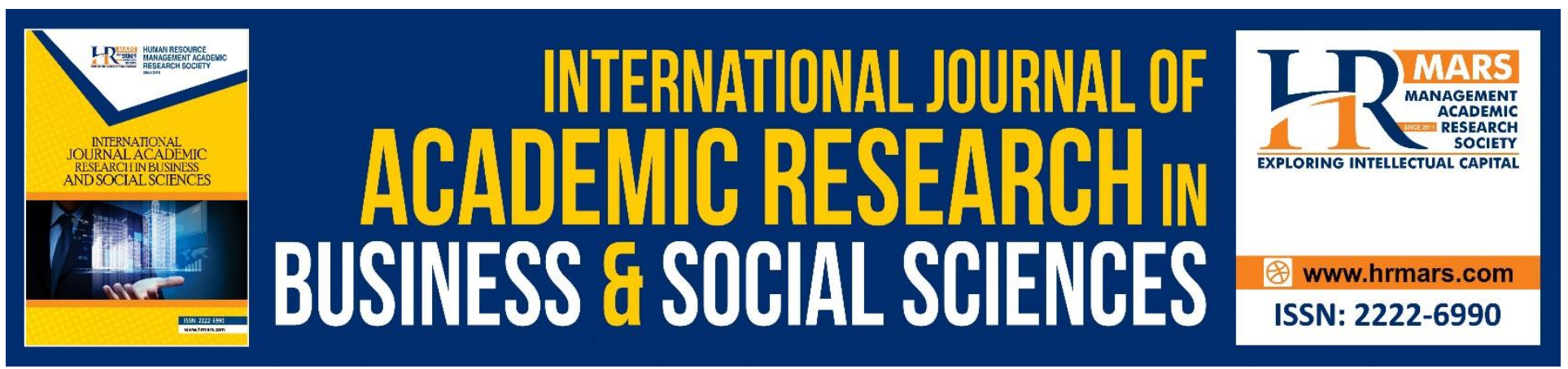

\title{
Teaching Professors' Challenges about Community Engagement Outreach and Intervention in Nigerian Universities
}

\author{
Samuel Outokunbo Adekalu \\ Faculty of Educational Studies, Universiti Putra Malaysia, Selangor, Malaysia \\ Email: adekaluolutokunbo@gmail.com \\ Steven Eric Krauss, PhD \\ Faculty of Educational Studies, Universiti Putra Malaysia, Selangor, Malaysia \\ Email: lateef@upm.edu.my \\ Ismi Arif Ismail, $\mathrm{PhD}$ \\ Faculty of Educational Studies, \\ Universiti Putra Malaysia, Selangor, Malaysia \\ Email: ismi@upm.edu.my \\ Turiman Suandi, PhD \\ Faculty of Educational Studies, \\ Universiti Putra Malaysia, Selangor, Malaysia \\ Email: tj@upm.edu.my
}

\begin{abstract}
Community engagement has been acknowledged as a core function of higher education, along with research and teaching which helps in promoting economic, environmental and socio-cultural development of communities. This article explores the barriers obstructing community engagement outreach and intervention in Nigerian higher education. Kwara State University, Malete, which adopted the philosophy of "the University for Community Development" is an interesting case in this study. Using in-depth semi-structured qualitative interviews, nine professors of the university were asked to reflect on how they sustained community engagement participation at different stages in their academic career. From data analysis, even though there are documentary evidences on the remarkable successes been achieved and reported with regards to community engagement activities and outreaches by the professors which helped to sustain professional identities and, in turn, career development. Four factors were found to be a barrier obstructing the professors' participation in
\end{abstract}


INTERNATIONAL JOURNAL OF ACADEMIC RESEARCH IN BUSINESS AND SOCIAL SCIENCES

Vol. 8, No. 8, August 2018, E-ISSN: 2222-6990 @ 2018 HRMARS

community engagement activities and outreaches. These were, (a) Educational gap between academics and community members, (b) lack of funds to execute community development projects, (c) time constraint due to multiple engagements, and (d) resistant to change by community members. The discussion and recommendations of this study are timely, as it concludes with a number of crucial issues that future community engagement in Nigerian higher education needs to be addressed.

Keywords: Academic Challenges, Community engagement, Career Development, Nigerian Universities

\section{Introduction}

Community engagement as strategy in developing career in academia has been undervalued in comparison to research and teaching which was not rewarded (Boyer, 1990; O'Meara, 2004; Neumann, 2005; O’Meara, 2008; Adekalu, Shuti, Turiman, Olohungbebe \& Adio, 2017; Adekalu, Ismail, Krauss \& Turiman, 2018a). Higher education often perceive research, teaching and community engagement outreach as separate elements of the academic continuum (O'Meara, 2004; Ogu, 2008; Moore \& Ward, 2010; Adekalu et al., 2018a) because community engagement is perceived as additional activities engaged by academics that contribute positively to the community wellbeing. Just like research and teaching activities that university academics engage in, community engagement has its own challenging attributes. Research and teaching in higher education have been traditionally prioritized as the major agenda and determinant for promotion of faculty members. This is because little attention is given to community engagement (Minkler, 2004; Buys \& Bursnall, 2007; Adekalu et al., 2017; Adekalu et al., 2018a). Kearny (2015) noted that, while some university academics that are potentially engaged, perceive community engagement as a means of career development, others perceive it as irrelevant to their job performance (Buys \& Bursnall, 2007; Adekalu et al., 2017). They also do not perceive it as an approach that can enhance their understanding of scholarship; neither do they perceive it as a legitimate approach which may be suitable for their research.

Holland and Ramaley (2008) explained that resistance to community engagement outreach may be partly because it has not been institutionalised in higher education system. For example, Cuthill and Brown (2010) who explored senior managers' perceptions of community engagement in a research intensive university in Australia, identified three different groups of academics based on their perceptions of community engagement. The three groups include; sceptics, utilitarian's and missionaries. The sceptics, who adopted the traditional perception of community engagement as extra activity, perceived community engagement as activities which is not part of the core activities of university and should therefore not affect the "real" work of universities (research and teaching). The second group which is the utilitarian's, perceived community engagement as relevant in some contexts and as a strategy which academics can use to achieve teaching and research outcomes. This group perceived community engagement as individual practice, instead of an important university practice. The third group which was identified in the study was missionaries; this group perceived community engagement as a civic imperative, this group stressed the importance of collaboration and mutual relationships between university and community. 
INTERNATIONAL JOURNAL OF ACADEMIC RESEARCH IN BUSINESS AND SOCIAL SCIENCES Vol. 8, No. 8, August 2018, E-ISSN: 2222-6990 @ 2018 HRMARS

\section{The Nigerian Context}

Since inception, university education in Nigeria serves as mechanism for national development. Meanwhile, teaching and research functions of university are expected to serve as a guide to the production of high level manpower and development of national awareness. Other functions include: dissemination of existing and new information, rendering of services to the community and being a storehouse of knowledge (Fafunwa, 2004; FGN, 2004). Notwithstanding, there has been an unlimited importance attached to universities globally, and in spite of this, universities do not often utilize their full capacity of general human and societal development. This can be seen in the Nigerian society reluctance attitude to university services and approaches of university community to the larger society. The two "university and community" do not critically link their services and issues of development and research to community engagement (Awwalu \& Najeemah, 2014; Adekalu et al., 2017; Adekalu et al., 2018a). While literature indicates the importance of having universities associated with social institutions and community development (Buys \& Bursnall, 2007; Kearny, 2015; Adekalu et al., 2017; Adekalu et al., 2018a). In additional to explore university education function to economic, social and moral development of the immediate and larger community (Gloria, 1997; Chatterton, 2000); if social and educational circumstances are made conducive to faculty member participation in community engagement practice, they have the potential to bridge this gap (Ifedili \& Ifedili, 2015).

Even though Nigeria has the largest universities in the Sub-Sahara Africa the documentary evidence of university and faculty members community engagement outreach is still lacking (Ifedili \& Ifedili, 2015; Adekalu et al., 2017; Adekalu et al., 2018a; Adekalu, Turiman, Krauss \& Ismail, 2018b). Despite universities were establish with the intention to contribute richly to the human resource, sociocultural and community development of the Nigerian states, unfortunately, the series of the academic activities such as research, teaching, community service being carried out in these universities are not measuring up with the public expectations (Ahmed, Umar \& Paul, 2015; Adekalu et al., 2017). In other words, these universities are performing below average standard. For example, in the global ranking of universities, none of the Nigerian universities appeared in the list of the top 6,000 universities in the world (Oyeneye, 2006). Till today, Nigerian universities are yet to be listed among the first 1000 top ranking institutions in the world (Quacquarelli Symonds (QS) World University Rankings, 2019). This development appears very frustrating when viewed against the backdrop that Nigeria once served as the nucleus of university education in the West-African subregion.

Knowledge creation and sharing through university community engagement outreach has been internationally recognized as a tool for national development, and Nigeria among developing country uprightly share in this view. Regrettably, inadequate access to research grants/funds for faculty members participation in community engagement initiatives in Nigeria, reveal why most universities in Nigeria are having problem to be rank among top best institution of higher learning when compare with other universities globally (Okujagu, 1998; Saint, Harnett \& Strassner, 2003; Okebukola, 2004; Egwunyenga, 2008; Akpan, Archibong \& Undie, 2011). Adesomoju (2008) reported that United State of America Federal Government single-handedly invests \$2.284 billion US Dollars to enhance research in U.S Universities and Colleges, while industries make available about $\$ 2.188$ billion US dollars in one (1) year to support research. In the study carried out by Millar and Senker (2000) it was discover that in many countries, above $50 \%$ of research funding comes from industries for related community projects. Reference to the reports, U.S.A., Sweden, Ireland, Germany and Belgium record industry funding of above $60 \%$; Korea and Japan above $70 \%$. These mentioned countries aim is to 
achieve world class excellence in university based research that can relatively have meaningful impacts to the community and making enough funding available for this purpose is an utmost priority to the government (Donwa, 2006). According to Bako (2005) less than $10 \%$ of the Nigerian university research is funded externally by international organizations and the same percentage by the university research board. For example, in a study conducted by Donwa (2006) it was reported that funding university research in Nigeria is done by the Government $(98.81 \%)$ and foreign bodies (1.19\%). This contributes to the challenges in accessing research grants by universities to engage in community work in Nigeria.

Today, it is worthy to note that, universities is no more looking upon as "ivory towers syndrome", but seen as an agent of change starting within it immediate surroundings as the current trend in academic industries is changing positively and more operationalize effectively in most developed countries due to globalization and all things that accompany it, this trend is still new in many developing countries institutions of higher learning like Nigeria, which warrant this research more imperative, to explore the challenges of community engagement activities in Nigerian Universities.

\section{Methodology}

This study adopted qualitative approaches to collect data from participant observations, case study, and in-depth semi structure interviews. The qualitative data also consist of interview transcripts, observations from the researcher, detailed descriptions from case study, field notes, and documents and academic and professional journal publications (Patton, 2002). Purposive sampling method was used in selecting nine university professors involved in community engagement. Kwara State University, Nigeria is the university in which the professors' work and they were selected using purposive sampling technique. This technique allows the researchers to choose specific samples that provide insights into the issues related to the study area (Alston \& Bowles 2003).

Nine university professors were used for the study. Some criteria were used to select the study participants; they were being a full professors, have Bachelor degree, Master degree and Doctor of Philosophy (PhD) or equivalent degrees from local or foreign government approved or recognized institution, have had at least fifteen years of career work experience in academic profession, sufficient experience and regular engagement in community service, received recognitions and awards within and outside of the university for community engagement activities in related field and acknowledged by the university authority. The study data were obtained at the Kwara State University, Malete, being an institution with the philosophy of community development. The university was approved as "the University for Community Development" by Kwara State Government with a reputation for excellence in teaching, research and community interventions.

The professors were from nine different academic backgrounds and departments at the Kwara State University. The participants were selected from within the College of Agriculture, Applied Sciences, Education, Engineering, Humanity, Information Communication Technology, and Social Sciences. Among the nine participants, seven were males and two were females. The age of the participants ranged from early 40s to early 70s, the average age being in the late 50s. They all had more than 15 years of work experience in academia. Within the sample, three of the professor had their doctoral degrees in Nigeria, while the remaining six had their Doctoral degrees from overseas institutions, namely the United States, United Kingdom, Netherlands, France, and Canada. They were all Nigerian nationals. 
INTERNATIONAL JOURNAL OF ACADEMIC RESEARCH IN BUSINESS AND SOCIAL SCIENCES Vol. 8, No. 8, August 2018, E-ISSN: 2222-6990 @ 2018 HRMARS

Each participant was interviewed between 1 to 4 times throughout the study. Each interview lasted approximately 20 minutes to 2 hours. A total of nineteen (19) one-on-one interviews were conducted. Documentary review was carried out during fieldwork when no interviews were being carried out. The documents were reviewed to support the data collected through interviews, participant observation, memos and field notes. The table (1) below shows details of the professors who participated in the research.

Table 1: Research Participants, College, Area of Expertise and Gender

\begin{tabular}{|c|c|c|c|}
\hline Participants & College & Area of Expertise & Gender \\
\hline PK1 & Agriculture & Plant bridging and Genetic & Male \\
\hline PK2 & Education & Sport Management & Male \\
\hline PK3 & Agriculture & Agricultural Extension & Male \\
\hline PK4 & Engineering & Soil and Water & Male \\
\hline PK5 & Humanity & Gender and English Literature & Female \\
\hline PK6 & Humanity & Linguistics & Female \\
\hline PK7 & Applied Science & Geology & Male \\
\hline PK8 & Social Science & Political Science & Male \\
\hline PK9 & ICT & Computer Science & Male \\
\hline
\end{tabular}

\section{Results and Discussion}

The responses to the main research question, what are the barriers to participation by university professors in community engagement? Provide an understanding to the barriers that obstruct community engagement activities among academics in Nigerian Universities. These include; Educational gap between academics and community members, lack of funds to execute community development projects, time constraint due to multiple engagements, and resistant to change by community members.

\section{Educational Gap between Academics and Community Members}

Participants explained different views by identifying low level of education as one of the barriers that professors whose area of community engagement is agriculture; they deal directly with farmers as they try to share new knowledge with farmers. The low level of education of the farmers made the farmers unable to understand what the professors were doing. This results into the professors taking more time to interact with them and understand them so that they understand the right way to deal with them when engaging community development projects. The participants added that their low level of education also slows down the process of executing community development projects because when the farmers don't understand what the professors are up to then they will not cooperate with them. Participant PK3 shared his experience saying:

"Well, one of the challenges is the low level of farmers' education; it is a challenge because it takes them time to understand what they should understand. But when you study them you will be able to understand them and communicate effectively".

He further stated that most times they have to first of all engage them in adult education programme to teach them the basic things needed to know before engaging in any forms of community engagement. He added the reason why they engage farmers in adult education programme is to build 
INTERNATIONAL JOURNAL OF ACADEMIC RESEARCH IN BUSINESS AND SOCIAL SCIENCES

Vol. 8, No. 8, August 2018, E-ISSN: 2222-6990 @ 2018 HRMARS

them up from their present level to communicate the language relevant to the existing practice the world is using. Participant PK1 also mentioned low level of education as one of the barriers which was explained from a different point. He said there is a need to educate the farmers about their intention because they are not aware of what is going on. He explained:

"The problem of education is that people are not aware that community engagement is collaborative work between the community and the researcher and as such the university and the community have to work hand-in-hand to encourage development. Not all of them are aware of this because some are still lagging behind".

This participants sees it as a challenge that needs to be address in order to bring about faster development. According to Bloomgarden and O'Meara (2007), many faculty members do not possess the experience and ability to directly deal with communities and the problems related to community engagement. Thus, there will be need for more experienced professors to handle such situations.

\section{Lack of Funds to Execute Community Development Projects}

Participants expressed that one of the barriers is the lack of funds to execute community development projects which they said cannot be successfully executed without. Some of them explained that even though the university provides grants for the execution of community development projects through the Center for Community Development, the funds are inadequate and inaccessible. Participant PK3 explained that corruption is one of the reasons why the funds are sometimes inaccessible. He stated: You see the problem in Nigeria is that money is never spent on worthwhile projects because of corruption and that is why we are where we are today. If we start spending money meant for community development projects in the right direction, the system will grow faster. He further stated that apart from the corruption, the delayed in release of funds due to bureaucratic procedure is another reason why funding has become a barrier to executing community development projects. To him, this bureaucratic procedure impedes the process of community engagement. He explained:

"Sometimes you spend your money because of the delay in release of funds thinking you will be refunded and at the end of the day you don't get your money back. So, instead of engaging more, you will withdraw and relax, so these are the problems. There is no logistics, for example there is no utility vehicle in the department or faculty and attempt to fuel your personal vehicle for the purpose of community development project, the issue of bureaucracy will not allow you to do that. You have to write to collect receipt and waited for a long time to get the money because the delays by auditors to audit and approve.

PK1 expressed the similar view with PK3 added that inadequate funding is a major barriers of community engagement. He stated that finance is a barrier because lack of it or its inadequacy can slow the process of development. So there is a need to overcome it so that the process can be faster. The participant said that in community development, money is required for different purposes. Apart from the need for money for the execution of projects, PK1 explained that money is needed for creating awareness on community development. He said: 
INTERNATIONAL JOURNAL OF ACADEMIC RESEARCH IN BUSINESS AND SOCIAL SCIENCES Vol. 8, No. 8, August 2018, E-ISSN: 2222-6990 @ 2018 HRMARS

"Funds are required to help promote this concept; there is need to put in more money so that more researchers can engage in community oriented projects. Researchers should be given a certain amount of money to go into the communities and create the awareness on projects they want to execute as the community members need to be aware of the community engagement of academics".

Participant PK4 also indicated that another problem related to funding is the control and disbursement of funds as identified by participant PK3. Participant PK4 said apart from the fact that the funds are not enough, those in control of the funds make it inaccessible by researchers. This participant added that even if the money is there it may be mismanaged and one may not be in the position to influence the management of the funds. So, many things will be left undone. He noted that this problem related to funding is detrimental to the achievement of goals which academics that engage in community development set for themselves. More so, he said that he sees this issue of funding as a barrier because it reduces motivation and discourages people from engaging in community development. He stated:

"Another challenge is that you can never have enough funds; you may have brilliant ideas but the funds may not be adequate. Sometimes, you are not really in-charge of the funds and the funds may be disbursed in a way that is detrimental to the goals you have set for yourself in community development. So this is one of the challenges that I have no solution to".

The engagement of faculty members can be prevented by inadequate financial support, lack of financial support or lack of monetary compensation for time invested in community work (Weerts \& Hudson, 2009). Even though, some faculty members are willing to invest their time in community engagement work, it is unwise to expect faculty members to invest extra time seeking external funding for their community engagement programs (Gorski \& Metha 2016). Therefore, the institutions should be able to give financial support to academics that are willing to run community engagement programs so that they will not be discouraged. According to Gorski \& Metha (2016) and Adekalu et al. (2017), external partners can help in funding community engagement projects; partnering with community members, the university and faculty members can gain extra sources of funding.

\section{Time Constraint Due to Multiple Engagements}

To some of the participants' time constraint is one of the barriers they experience in community engagement. They explained that as professors they engage in many things such as teaching a large number of students, supervising so many students and conducting researches yet they have to engage in community development. The participants said despite this constraint, they still try to create little time for community engagement. Participant PK9 said:

"As a professor you have limited time and many departments have just few professors. So these professors engage in many things, look at the number of courses that you need to teach and look at the number of student you need to supervise, so you don't even have the time to engage in community activities, but because it is essential you 
INTERNATIONAL JOURNAL OF ACADEMIC RESEARCH IN BUSINESS AND SOCIAL SCIENCES Vol. 8, No. 8, August 2018, E-ISSN: 2222-6990 C 2018 HRMARS

have to manage your little time. The major challenge I still have is time to participate in community activities".

Likewise participant PK6 who shared the same experience with participant PK9 had this to say: Yah.... The challenge is the time to engage in community development activities, to get the time to engage is difficult but you have to create time and you have to be really interested in it if not you will not be able to continue.

She further explained the important for community engagement activities to involve other people so that if the problem of time comes in, the project will not be abandoned. However, she still emphasized on the need to engage in whatever way even if it is not a big project; one should be able to contribute to the development of the community. Thus she said:

\begin{abstract}
"So, I said find the time, it's not easy to create time but create time for it, it could be a weekend, it shouldn't be a long time; it can be just 1 hour staying with students and tutoring them. There are so many ways that you can help, so it's not just in terms of doing big things. You can do it in your own small way, is still community service. You can teach them small craft as well as computer operation tutor; you know we have so much to offer. Every faculty staff should try to create time for it".
\end{abstract}

Recent studies revealed that faculty members are expected to simultaneously excel in research, teaching and outreach (O'Meara \& Braskamp, 2005). These multiple commitments of faculty members make their job more stressful (Bloomgarden \& O'Meara 2007). Gorski and Metha (2016) further explained that apart from major roles like teaching, research and outreach which faculty members play, they are also expected to organize, make logistics for and plan community engagement projects while building relationships with community which is a long term activity that is time-consuming.

The finding of this study is entirely consistent with the finding of an annual survey carried out by Campus Compact annual which showed that one of the obstacles to community engagement is the pressures which faculty work puts on faculty members (Campus Compact, 2003). They further explained that it is important for those who engage in community development activities to involve other people so that if the problem of time comes in, the project will not be abandoned. This opinion of the participants is similar to that of Gorski and Metha (2016) who suggested that engagement work can be supported by both professional and non-professional staff so that the time consumed by community engagement can be reduced. Despite, the professors' complain about time constraint, they still emphasized on the need to engage in whatever way even if it is not a big project; one should be able to contribute to the development of the community.

\title{
Resistance to Change by Community Members
}

Participants expressed different views; some of them indicated resistance to change by the community members. They explained that often times the community members will listen to the professors when they are communicating their intentions but when it is time for implementation they are not willing to co-operate; they begin to pull back. One of the participants who experienced this attitude, said the reason why the members of the community showed unwillingness to accept 
INTERNATIONAL JOURNAL OF ACADEMIC RESEARCH IN BUSINESS AND SOCIAL SCIENCES

Vol. 8, No. 8, August 2018, E-ISSN: 2222-6990 @ 2018 HRMARS

the change initiative is because they have old practices which they are used to and do not want anything new because they are unsure of how beneficial it will be to them. Also, participant PK2 who had similar experience said sometimes the community members were resistant to change because the new idea or practice which is brought by the community members is not in accordance with their culture. He explained:

"There is always this resistance to change, even in a household where people are eating something and suddenly they want to change because of a number of reasons. There is always resistance to change definitely. If you are the initiator of a community programme they can resist the programme saying this is not what we do here. It's not in line with our culture. This can discourage one from continuing but if you persist they may later support you".

He also added the reasons why the people resist change is as a result of trust issues. He said that sometime the people resist a change initiative because they do not believe in the initiator of the change programme as well as the change programme itself. He shares his experience saying: majorly, the challenge is to get people to believe in whatever you want to do. Sometime this makes people to have some level of reluctance towards community development projects.

This participant referred to this as a challenge because without the co-operation of the people one cannot execute community development projects. He said it very important to have the support of the people if not one will not be successful. Similarly, Participant PK1 stated that the community members usually resist change because sometimes they do not understand what the community development project is all about. This participant said one way to overcome this barrier is to educate the people on the project so that they can have a better understanding thereby co-operating with academics in the implementation of their community development projects. He stated that if the cooperation is not there then the project will be a failure.

More so, participant PK4 earlier stated that interaction is one of the most important ways of overcoming this resistance. He said that it is only through interaction that trust can be built thereby resulting in co-operation of the community members. He said:

"You must get to the people and interact with the people in order to understand their problems and seek what they want; don't try to do this on your own. It's through interaction with them that you get to know that this is what they want. So it's only to get them on the same track with you; don't impose anything on them".

This resistance to change can be explained using Rogers (1962) diffusion of innovation theory. According to Rogers, if the new idea, innovation or practice which is being advocated for does not fit into the pre-existing system then the community may resist such change initiative. Therefore, academics who engage in community development must ensure that whatever new practice, idea or innovation they intend to diffuse to a community fits into the pre-existing system in one or the other so as to avoid this resistance which can cripple their community engagement. According to the Centre for Economic and Community Development, Penne State College of Agricultural Sciences (2017), relationship building fosters trust building. The Centre in its article titled "the role and importance of 
INTERNATIONAL JOURNAL OF ACADEMIC RESEARCH IN BUSINESS AND SOCIAL SCIENCES

Vol. 8, No. 8, August 2018, E-ISSN: 2222-6990 @ 2018 HRMARS

building trust" further noted that if conscious and consistent effort is not made to build strong relationships that can foster trust, even the most properly designed and well-meaning community engagement project will be a failure or will not be as successful as desired.

\section{Conclusion and Recommendations}

This study contributed towards a greater understanding of the experiences of professors' community engagement in a Nigerian university at different stages in their careers. Different views and experiences shared by the study participants in relation to their engagement in community development projects reveals insights on their driving force for community development, the contribution(s) which community engagement makes to their academic career and the barriers that stand against community engagement outreach.

Also, it is crucial that institution of higher learning, particularly university should continue to serve as a change agents and medium to promote economic and socio-cultural development by involving immediate communities in their scholarly research projects in order to offer the necessary skills and attitudes that will assist to enhance quality of life. Universities should recognize community development activities as key performance indicator for academic promotion and students awards. Universities and other tertiary institutions should draw programs based on the needs of their immediate communities and not just import curricula. More so, faculty members and students should be supported for community engagement so as to reduce the work load of the professors that face the challenge of time constraint in community engagement leading to abandonment of community development projects. Lastly, in order to overcome the barrier of resistance, we suggested that trust between the university and communities should be built first, between the university and community.

The essences of research works is not just to produce and arrange it on a shelf, and allow it to be gathering dust; it should have a positive impact on the community and be given the needed supports by the university, stakeholders, government, and interested individual enlisted to make it a large success. This study, like many other studies have some limitations. One of them is the scope; the study was only conducted among professors, the researchers suggest that future studies should include non-academic staff of tertiary institutions.

\section{Acknowledgement}

This study was supported by Petroleum the Technology Development Fund (PTDF) Nigeria.

\section{References}

Adekalu, S. O., Ismail, A. I., Krauss, S. E., \& Turiman, S. (2018). Developing Career through Community Engagement: The Nigerian University Experience. International Journal of Education and Literacy Studies, 6(3): 99-107.

Adekalu, S. O., Krauss, S. E., Turiman, S., \& Ismail, I. A. (2017b). Exploring the Personal Philosophies of Volunteerism among Professors at a Malaysian Research University. OUSL Journal, 12(1), 91-108.

Adekalu, S. O., Shitu, M. B., Turiman, S., Olohungbebe, L. O., \& Adio, A. A. (2017a). Facilitating Community Development through Institutional Engagements: Reflections from 2016 Nigeria IACD Conference. Journal of Resources Development and Management, 30, 132-140. 
INTERNATIONAL JOURNAL OF ACADEMIC RESEARCH IN BUSINESS AND SOCIAL SCIENCES Vol. 8, No. 8, August 2018, E-ISSN: 2222-6990 @ 2018 HRMARS

Adekalu, S. O., Turiman, S., Krauss, S. E., \& Ismail, A. I. (2018). Motivating Factors of Community Engagement Practice among Professors in Nigerian Universities. International Journal of Research in Management, 8(1): 1-14.

Adesola, A. O. (1991). The Nigerian university system: meeting the challenges of growth in a depressed economy. Higher Education, 21(1): 121-133.

Adesomoju, A. (2008). Attracting Grants from the organized Private Sector in Postgraduate Research and Development. A paper presented at the 4th National Workshop of Committee of Deans of Postgraduate Schools in Nigerian Universities, on Involvement of Industries and the organized Private Sector in Postgraduate Research for National Development. Abuja, 16-17 April, 2008.

Ahmed, T, Umar, K. \& Paul, C. (2015). Analysis of Factors Enhancing Pitfall in Research and Teaching of the Nigerian University System. International Journal of Higher Education, 4(3): 82-89.

Akpan, C. P., Archibong, I. A. \& Undie, J. A. (2011). Lecturers' Access to Research Fund in Nigerian Universities: Challenges and Strategies for Improvement. Available at http://socioumane.ro/blog/analesocioumane/files/2011/04/Akpan-Archibong-Undie.pdf. Retrieved on March 27, 2016.

Akinyemi, S. \& Potokri, O. C. (2016). Inequitable access to the knowledge market in Nigeria: The case of university education. Industry and Higher Education, 30(6): 424-432.

Alston, M. \& Bowles, W. (2003). Research for social workers: an introduction to methods, 2nd edn, Allen \& Unwin, NSW, Australia.

Bako, S. (2005). Universities, Research and Development in Nigeria: Time for Paradigmatic Shift. Paper prepared for the 11th General Assembly of CODESRIA on Rethinking African Development beyond Impasse: Towards Alternatives. Maputo, Mozambique, 6th - 8th December.

Boyer, E. L. (1990). Scholarship reconsidered: priorities of the professoriate. Princeton, NJ: Carnegie Foundation for the Advancement of Teaching.

Bloomgarden, A. H. \& O'meara, K. (2007). Faculty Role Integration and Community Engagement: Harmony or Cacophony? Michigan Journal of Community and Service Learning, MicSpring 2007, 5-18.

Buys, N., \& Bursnall, S. (2007). Establishing university-community partnerships: Processes and benefits. Journal of Higher Education Policy and Management, 29(1), 73-86.

Campus Compact (2003). Campus Compact Annual Membership Survey, 2003. Available at http://www.compact.org/ about/statistics/2003/service-learning_development, Retrieved on June 14, 2017.

Centre for Economic and Community Development, Penne College of Agricultural Science (2017). The role and importance of building trust. Available at http://aese.psu.edu/research/centers/cecd/engagement-toolbox/role-importance-ofbuilding-trust. Retrieved on May 3, 2017.

Chatterton, P. (2000). The cultural role of universities in the community: revisiting the universitycommunity debate. Environment and Planning A, 32(1): 165-182.

Cuthill, M., \& Brown, A. (2010). Sceptics, utilitarians and missionaries: Senior managers' perceptions of engagement in a research intensive Australian university. Australasian Journal of University-Community Engagement, 5(2): 126-146.

Das, T. H. (1983). Qualitative research in organizational behavior. Journal of Management Studies, 20(3), 301-314. 
INTERNATIONAL JOURNAL OF ACADEMIC RESEARCH IN BUSINESS AND SOCIAL SCIENCES Vol. 8, No. 8, August 2018, E-ISSN: 2222-6990 @ 2018 HRMARS

Donwa, P. A. (2006). Funding of Academic Research in Nigerian Universities. A paper presented at the UNESCO forum on Higher Education Research and Knowledge creation. November 29December 1, 2006. Available at http://portal.unesco.org/educationfr/files. Retrieved on July 8, 2017.

Egwunyenga, E. J. (2008). Dystrophies and Associated Crisis in Research and Academic Publication in Nigerian Universities. Anthropologist, 10(4): 245-250.

Fafunwa, A. B. (2004). History of education in Nigeria. Ibadan: NPS Educational Publisher Ltd.

FGN. (2004). National policy on education (4th ed.). Abuja: Nigerian: Federal Government of Nigeria.

Gloria, A. M. (1997). Chicana Academic Persistence Creating a University-Based Community. Education and Urban Society, 30(1): 107-121.

Gorski, I. \& Metha, K. (2016). Engaging Faculty across the Community Engagement Continuum. Journal of Public Scholarship in Higher Education, (6), 108-123.

Holland, P., \& Ramaley, J. (2008, July). Creating a supportive environment for community-university engagement. Paper presented at HERDSA Annual Conference, Rotorua, New Zealand.

Ifedili, C. J. and Ifedili, C. (2015). Management of Nigerian Universities and Community Services, European Journal of Business and Social Science, 4(9): 14-21.

Kearney, J. (2015). Challenges for Community Engagement: An Australian Perspective. Educational Research for Social Change (ERSC), 4(1): 26 - 39.

Millar, J. \& Senker, J. (2000). International Approaches to Research Policy and Funding: University Research Policy in Different National Contexts. Brighton: SPRU.

Minkler, M. (2004). Ethical challenges for the "outside" researcher in community-based participatory research. Health Education \& Behavior, 31(6): 684-697.

Moore, T., \& Ward, K. (2010). Institutionalizing faculty engagement through research, teaching, and service at research universities. Michigan Journal of Community Service Learning, Fall, 44- 58.

Neumann, A. (2005). Observations: Taking seriously the topic of learning in studies of faculty work and careers. Advancing faculty learning through interdisciplinary collaboration, 63-84. New Directions for Teaching and Learning, 102. San Francisco: Jossey-Bass.

Odukoya, D. (2013). Formulation and implementation of educational policies in Nigeria. http://www.slideshare.com. Retrieved on March 8, 2017.

Ogu, E. (2008). Challenges Facing Nigerian Universities. Available at http://nigeriaworld.com/articles/2008/sep/300.html. Retrieved on April 23, 2017.

Okebukola, P. (2004). Strategies for Stimulating Researches and Development in Nigerian Universities. Nigerian University Chronicles, 12(2): 17-18.

O’Meara, K. \& Braskamp, L. (2005). Aligning faculty reward systems and development to promote faculty and student growth. NASPA Journal, 42(2): 223-240.

O'Meara, K. (2008). Motivation for faculty community engagement: Learning from exemplars. Journal of Higher Education Outreach and Engagement, 12(1): 7-29

O'Meara, K. (2004). Reframing incentives and rewards for community service learning and academic outreach. Journal of Higher Education Outreach and Engagement 8(2): 201-20.

Oyeneye, O. (2006) Current Issues in the Administration of University Education in Nigeria. Lecture delivered at the 5th Convocation Ceremony of the University of Ado-kiti, Ekiti State, Nigeria, March, 29.

Patton, M. (2002). Qualitative Research \& Evaluation Methods. Thousand Oaks, CA: Sage Publications. 
INTERNATIONAL JOURNAL OF ACADEMIC RESEARCH IN BUSINESS AND SOCIAL SCIENCES

Vol. 8, No. 8, August 2018, E-ISSN: 2222-6990 @ 2018 HRMARS

Quacquarelli Symonds (QS) World University Rankings (2019). Quacquarelli Symonds (QS) Top Universities, Available at https://www.topuniversities.com/university-rankings. Retrieved on August 25, 2018.

Weerts, D., \& Hudson, E. (2009). Engagement and institutional advancement. New Directions for Higher Education, (147): 65-74. 